\title{
Performance and kinetic modeling of modified attached-growth anoxic-oxic-anoxic reactor for onsite sanitation system treating septic tank effluent
}

\author{
Thammarat Koottatep ${ }^{1}$, Sittikorn Kamngam ${ }^{1+}$, Chawalit Chaiwong ${ }^{1}$, Chongrak Polprasert ${ }^{2}$ \\ ${ }^{1}$ Environmental Engineering and Management, School of Environment, Resources and Development, Asian Institute of Technology, Pathumthani, \\ 12120, Thailand \\ ${ }^{2}$ Department of Civil Engineering, Faculty of Engineering, Thammasat University, Pathumthani, 12120, Thailand
}

\begin{abstract}
This paper investigated a combined process of a modified attached-growth anoxic-oxic-anoxic reactor (AG-AOAR) as a sustainable and effective post-treatment system for septic tank effluent was developed. The AG-AOAR was operated by varying hydraulic retention times (HRTs) from 24 to $72 \mathrm{~h}$. The results showed that the AG-AOAR achieved highest removal efficiencies of 84,66 and $91 \%$ of chemical oxygen demand (COD), total nitrogen $(\mathrm{TN})$ and ammonium nitrogen $\left(\mathrm{NH}_{4}-\mathrm{N}\right)$, respectively, under the HRT of $72 \mathrm{~h}$, resulting its effluent meeting the international and national discharge quality standards for non-sewered sanitation system. The Stover-Kincannon model was applicable to describe the kinetic constants of $\mathrm{COD}, \mathrm{TN}$, and $\mathrm{NH}_{4}-\mathrm{N}$ removal in the AG-AOAR $\left(\mathrm{R}^{2}>0.85\right)$. Accordingly, the maximum utilization rates $\left(\mu_{\max }\right)$ were determined to be 41.1 , 0.15 and $0.50 \mathrm{~g} /(\mathrm{L}-\mathrm{d})$ for COD, $\mathrm{TN}$ and $\mathrm{NH}_{4}-\mathrm{N}$ removals, respectively, while the saturation constants $\left(\mathrm{K}_{\mathrm{B}}\right)$ were $57.7,0.12$ and $0.51 \mathrm{~g} /(\mathrm{L}-\mathrm{d})$, respectively. These constant values could be applied for the design of the AG-AOAR to produce treated effluent meeting desired standards.
\end{abstract}

Keywords: Attached-growth, Anoxic-oxic-anoxic, Septic tank effluent, Stover-Kincannon model

\section{Introduction}

In rural and urbanizing areas of developing countries, the conventional onsite sanitation systems especially, septic tanks are widely used to treat grey and toilet wastewater [1]. Nevertheless, performance of these septic tanks could fail at some points, resulting in high effluent concentrations of organic and nutrient matters. Hence, discharging the septic tank effluent without further treatment to the environment could lead to environmental and human health problems [2]. Furthermore, the United Nations Sustainable Development Goals aim to provide clean water and sanitation (Goal 6) for more than 2.4 billion people currently being without proper sanitation [3]. Recently, there are numerous reports of upgrading performance of the onsite systems which normally focus on organics and solid removals, but high of total nitrogen (TN) were still found in the effluent [4]. Because the TN needs to be managed appropriately, the biological nutrient removal processes such as nitrification/ denitrification have been applied for enhancing TN removal. To provide more surface area for bacterial growth, higher biomass density and treatment performance, the attached-growth rather than the suspended-growth has been used as a post-treatment system [5]. Furthermore, zeolite having a high surface area for bacterial growth and capable of adsorptive capacity, has been suggested to be used for wastewater treatment [6]. Nitrifying and denitrifying bacteria can grow on the zeolite surface; hence, the zeolite can increase TN removal via nitrification/denitrification processes.

On the basis of the above considerations, the modified attached-growth anoxic-oxic-anoxic reactor (AG-AOAR) was developed and applied as an effective on-site post-treatment unit by arranging different types of attached-growth media, namely, ball ring®, transparent plastic sheets and zeolite beads for the growth of bacteria for enhancing organic and TN removals. Biological processes can be designed based on the parameters such as organic,
This is an Open Access article distributed under the terms of the Creative Commons Attribution Non-Commercial License (http://creativecommons.org/licenses/by-nc/3.0/) which permits unrestricted non-commercial use, distribution, and reproduction in any medium, provided the original work is properly cited.

Copyright (C) 2022 Korean Society of Environmental Engineers
Received November 09, 2020 Accepted March 29, 2021

${ }^{\dagger}$ Corresponding author

E-mail: sittikornkam@gmail.com

Tel: +66832830309

ORCID: 0000-0002-2537-3247 
nutrient loading rates and hydraulic retention times (HRTs), in which the process modeling should be applied to describe and predict the performance and optimal operating conditions of the modified AG-AOAR. To evaluate a suitable reactor design, the determination of kinetic coefficients should be performed [7]. The Stover-Kincannon model has been widely applied to describe the organics and nitrogen removal in reactor particularly in attached-growth systems [8-10]. However, there are few studies on the determination of biodegradation kinetic values for attached-growth arrangement processes or AG-AOAR system treating septic tank effluent. Therefore, onsite post-treatment system technology based on biological processes, such as the modified AG-AOAR is considered as a sustainable and effective solution for pollution control.

This study aimed to evaluate the treatment performance of the modified AG-AOAR as a sustainable and cost-effective post-treatment system in treating septic tank effluent, which was also expected to effectively remove high chemical oxygen demand (COD) and TN concentrations and to determine the kinetic values to be used for an appropriate design of the modified AG-AOAR.

\section{Materials and Methods}

\subsection{Experimental Set-up}

The lab-scale experiment of the modified AG-AOAR was carried out at the Asian Institute of Technology (AIT) campus, Pathumthani, Thailand. The modified AG-AOAR was fabricated from transparent acrylic plastic to have dimension of $150 \mathrm{~cm}$ (width), $400 \mathrm{~cm}$ (depth), and $600 \mathrm{~cm}$ (length), resulting its working volume of $27 \mathrm{~L}$. The modified AG-AOAR consisted of three sections in series, namely anoxic $1\left(\mathrm{~A}_{1}\right)$ (working volume of $3 \mathrm{~L}$ ), oxic $\left(\mathrm{O}_{1}\right)$ (working volume of $18 \mathrm{~L}$ ) and anoxic $2\left(\mathrm{~A}_{2}\right)$ (working volume of $6 \mathrm{~L}$ ) as shown in Fig. 1(a). Furthermore, five acrylic baffles were equipped inside responsible to create up-and-down flow patterns of wastewater which could result in better contact between bacteria and wastewater accordingly to the up-flow mode as well as to allow gravity flow between the sections designed (Fig. 1(a)). To allow attached microbial growth, three different types of attached-growth media (Fig. 1(b)) namely, ball rings ${ }^{\circledR}$ (industrial media made of polyethylene $(35 \times 35 \mathrm{~mm}$ of length $\times$ height), plastic strips (a low-cost media made of plastic recycled bottle having diameter (Ø) of 120

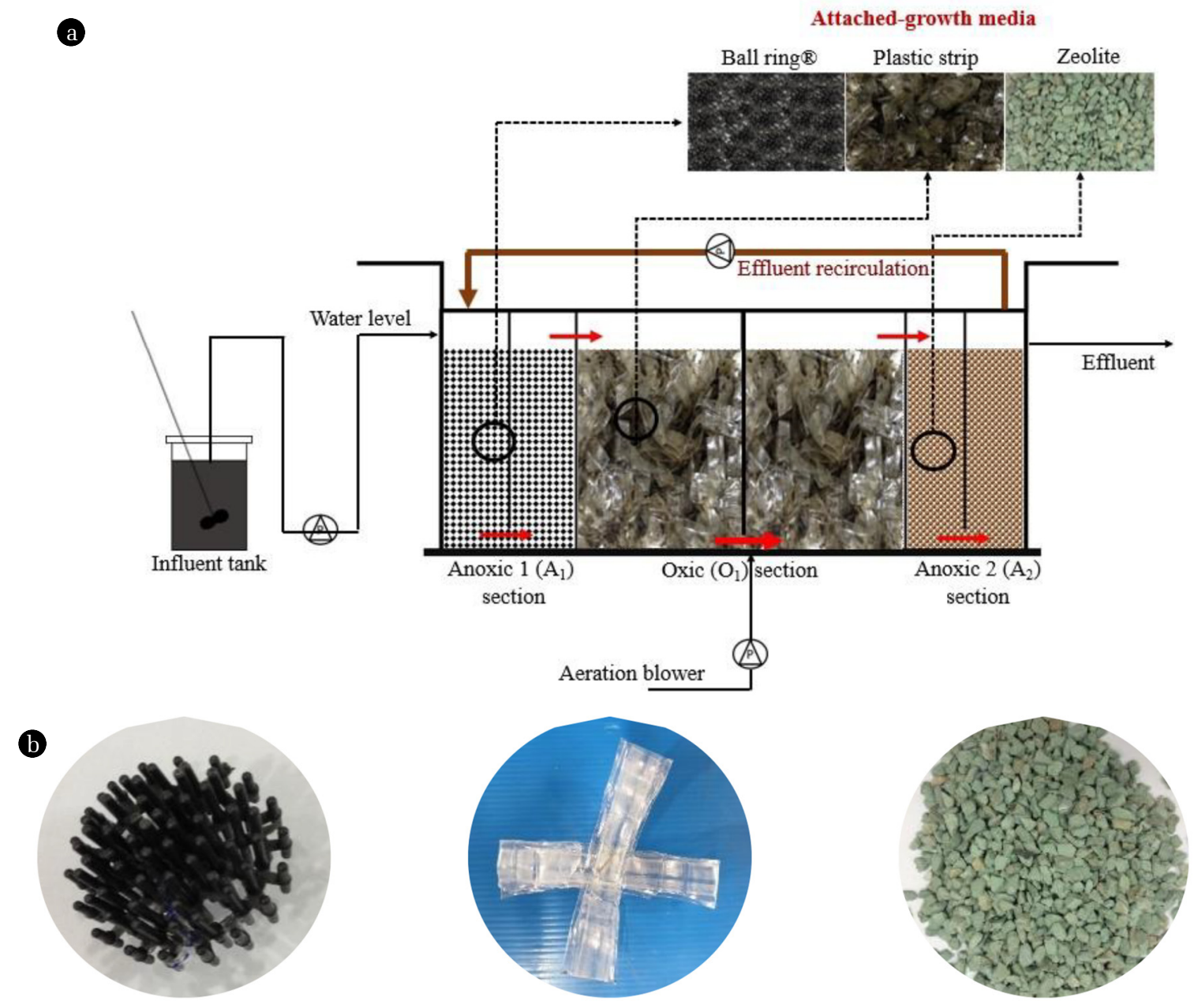

Fig. 1. (a) Experimental setup of the modified AG-AOAR and (b) media types. 
$\mathrm{mm})$, and zeolite beads $(\varnothing=1.80 \mathrm{~mm}$ ) were placed inside of the $\mathrm{A}_{1}, \mathrm{O}_{1}$ and $\mathrm{A}_{2}$ sections, respectively, The specific areas and porosities of the ball rings ${ }^{\circledR}$, the plastic strips and the zeolite beads were 200, 210 and $43 \mathrm{~m}^{2} / \mathrm{m}^{3}$, and 93,92 and $47 \%$, respectively.

\subsection{Source of Wastewater and Its Characteristics}

The septic tank effluent collected weekly from the septic tanks in households located in Pathumthani, Thailand, was used as influent wastewater for feeding to the modified AG-AOAR system. The influent wastewater contained COD, TN, ammonium nitrogen $\left(\mathrm{NH}_{4}-\mathrm{N}\right)$, and total suspended solids (TSS) concentrations of 535 \pm 369, $184 \pm 3,162 \pm 8 \mathrm{mg} / \mathrm{L}$ and 1,052 $\pm 838 \mathrm{mg} / \mathrm{L}$, respectively, corresponding to the characteristics of high strength domestic wastewater [11]. Accordingly, the COD:TN ratio of the influent wastewater was 3:1, which was in the suitable range of 3-4 for the biological nitrogen removal processes (i.e. nitrification/denitrification processes) [12].

\subsection{Operating Conditions}

In this study, activated sludge collected from the wastewater treatment plant of the AIT campus, was used as bacterial inoculum in the modified AG-AOAR. The activated sludge was put into the $\mathrm{O}_{1}$ section, carried out under the temperature of $27.2 \pm 0.9^{\circ} \mathrm{C}$ and $\mathrm{pH}$ in the ranges of $6-7$ for $30 \mathrm{~d}$, adequate for a tangible bacterial growth on the media. Meanwhile, aeration was supplied maintain to dissolved oxygen (DO) concentration above $2 \mathrm{mg} / \mathrm{L}$, ensuring aerobic conditions eligible for biological organic oxidation and nitrification reactions [13]. The influent wastewater was continuously fed to the $\mathrm{A}_{1}$ section of the modified AG-AOAR by a peristatic pump, operated by varying HRTs of 24 to 72 $\mathrm{h}$, corresponding to organic loading rate (OLR), nitrogen loading rate (NLR) and ammonium loading rate $\left(\mathrm{NH}_{4} \mathrm{LR}\right)$ were 0.69 to $0.25 \mathrm{gCOD} /(\mathrm{L}-\mathrm{d}), \quad 0.19$ to $0.05 \mathrm{gN} /(\mathrm{L}-\mathrm{d})$ and 0.16 to 0.05 $\mathrm{gNH}_{4}-\mathrm{N} /(\mathrm{L}-\mathrm{d})$, respectively, as revealed in Table 1 . The internal recirculation from $A_{2}$ to $A_{1}$ with $100 \%$ of influent flowrate were operated to enhance $\mathrm{TN}$ removal by denitrification processes $[14,15]$.

Table 1. Operational Conditions Throughout Experiments

\begin{tabular}{|c|c|c|c|}
\hline Parameter & \multicolumn{3}{|c|}{ Experimental operating conditions } \\
\hline OLRs, gCOD/(L-d) & 0.69 & 0.34 & 0.25 \\
\hline NLRs, gN/(L-d) & 0.19 & 0.08 & 0.05 \\
\hline $\mathrm{NH}_{4} \mathrm{LRs}, \mathrm{gNH}_{4}-\mathrm{N} /(\mathrm{L}-\mathrm{d})$ & 0.16 & 0.08 & 0.05 \\
\hline HRTs (h) & 24 & 48 & 72 \\
\hline Duration (d) & 12 & 22 & 38 \\
\hline
\end{tabular}

\subsection{Analytical Methods}

The influent and effluent samples of the modified AG-AOAR were collected three times a week during the experimental operating period of $72 \mathrm{~d}$ for laboratory analysis. The parameters including COD, TKN, $\mathrm{NH}_{4}-\mathrm{N}$ and TSS concentrations were analyzed according to the Standard Methods [16], while nitrate $\left(\mathrm{NO}_{3}-\mathrm{N}\right)$ and nitrite $\left(\mathrm{NO}_{2}-\mathrm{N}\right)$ concentrations were analyzed by a portable analyzer (HACH DR-2700, Germany) according to the manufacturer procedures. The $\mathrm{pH}, \mathrm{DO}$ and temperature values were also continuously monitored using a multiparameter portable meter (HATCH-HQ40d, USA).

\subsection{Kinetic Model}

In this study, the Stover-Kincannon model was used for determining the kinetic constants of $\mathrm{COD}$, TN, and $\mathrm{NH}_{4}-\mathrm{N}$ removal in the modified AG-AOAR. This kinetic model was originated for determining kinetic constants of a rotating biological contactor [8]. Later, the model has been applied to attached-growth system to describe the kinetics of other types of biofilm reactor [9, 17]. This kinetic model was based on substrate removal rates against a function of the substrate loading rate in the in the modified AG-AOAR as described by Eq. (1) and (2),

$$
\begin{gathered}
\frac{\mathrm{ds}}{\mathrm{dt}}=\frac{\mu_{\max }\left(\mathrm{QS}_{\mathrm{o}} / \mathrm{V}\right)}{\mathrm{K}_{\mathrm{B}}+\left(\mathrm{QS}_{0} / \mathrm{V}\right)} \\
\frac{\mathrm{ds}}{\mathrm{dt}}=\frac{\mathrm{Q}}{\mathrm{V}}\left(\mathrm{s}_{\mathrm{o}}-\mathrm{s}\right)
\end{gathered}
$$

The Eq. (1) and Eq. (2) can be combined as Eq. (3)

$$
\frac{\mathrm{V}}{\mathrm{Q}\left(\mathrm{S}_{\mathrm{o}}-\mathrm{S}_{\mathrm{e}}\right)}=\frac{\mathrm{K}_{\mathrm{B}}}{\mu_{\max }} \frac{\mathrm{V}}{\mathrm{QS}_{\mathrm{o}}}+\frac{1}{\mu_{\max }}
$$

where, $S_{0}$ and $S_{e}$ are the influent and the effluent substrate concentrations $(\mathrm{g} / \mathrm{L}), \mu_{\max }$ is the maximum utilization rate $(\mathrm{g} /(\mathrm{L}-\mathrm{d})), \mathrm{K}_{\mathrm{B}}$ is saturation constant $(\mathrm{g} /(\mathrm{L}-\mathrm{d})), \mathrm{V}$ is reactor volume $(\mathrm{L}), \mathrm{Q}$ is flowrate $(\mathrm{L} / \mathrm{d})$ and $\mathrm{ds} / \mathrm{dt}$ is substate removal rate $(\mathrm{g} /(\mathrm{L}-\mathrm{d}))$. The plotting of $\mathrm{V} /\left(\mathrm{Q}\left(\mathrm{S}_{0}-\mathrm{S}_{\mathrm{e}}\right)\right)$, invest of the loading removal rate versus $\mathrm{V} /\left(\mathrm{QS}_{\mathrm{o}}\right)$, invest of the total loading rate can be described a straight line. The intercept and slop of the line result in $1 / \mu_{\max }$ and $K_{B} / \mu_{\max }$, respectively. The substrate occurred for effective reactor volume can be re-written following.

$$
\mathrm{QS}_{\mathrm{o}}=\mathrm{QS}_{\mathrm{e}}+\mathrm{V}\left(\frac{\mathrm{ds}}{\mathrm{dt}}\right)
$$

Hence, the substitution of Eq (3) to (4) was expressed as

$$
\mathrm{QS}_{\mathrm{o}}=\mathrm{QS}_{\mathrm{e}}+\frac{\mu_{\max }\left(\mathrm{QS}_{\mathrm{o}} / \mathrm{V}\right)}{\mathrm{K}_{\mathrm{B}}+\left(\mathrm{QS}_{\mathrm{o}} / \mathrm{V}\right)} \times \mathrm{V}
$$

Furthermore, the reactor effluent and volume can be determined by Eq (6) and (7)

$$
\begin{gathered}
\mathrm{S}_{\mathrm{e}}=\mathrm{S}_{\mathrm{o}}-\frac{\mu_{\max } \mathrm{S}_{\mathrm{o}}}{\mathrm{K}_{\mathrm{B}}+\left(\mathrm{QS}_{\mathrm{o}} / \mathrm{V}\right)} \\
\mathrm{V}=\frac{\mathrm{QS}_{\mathrm{o}}}{\left(\mu_{\max } \mathrm{S}_{0} / \mathrm{S}_{0}-\mathrm{S}_{\mathrm{o}}\right)-\mathrm{K}_{\mathrm{B}}}
\end{gathered}
$$

\subsection{Statistical Analysis}

The significant differences among the data measured were tested with the analysis of variance (ANOVA) in SPSS software (V.16.0). 


\section{Results and Discussions}

During the start-up period of this study, it was found that the steady-state conditions with respect to relatively stable removal rates of $\mathrm{COD}, \mathrm{NH}_{4}-\mathrm{N}$ and $\mathrm{TN}$ were achieved within $30 \mathrm{~d}$. The $\mathrm{pH} \mathrm{DO}$ and temperature at different sections in the modified AG-AOAR were monitored. DO concentrations in the $\mathrm{A}_{1}, \mathrm{O}_{1}$ and $\mathrm{A}_{2}$ sections were found to be $0.4 \pm 0.2,4.6 \pm 0.4$ and $0.6 \pm 0.2$ $\mathrm{mg} / \mathrm{L}$, respectively. The average $\mathrm{pH}$ and temperature values were recorded to be $7.1 \pm 0.3,7.2 \pm 0.4$ and $7.4 \pm 0.4$ and $27.6 \pm$ $0.9,26.3 \pm 0.9$ and $27.7 \pm 0.9$ in the $A_{1}, O_{1}$ and $A_{2}$ sections, respectively. The DO concentrations of more than $2 \mathrm{mg} / \mathrm{L}$ in the $\mathrm{O}_{2}$ section were suitable for the nitrification processes to convert $\mathrm{NH}_{4}-\mathrm{N}$ to $\mathrm{NO}_{2}-\mathrm{N}$ and $\mathrm{NO}_{3}-\mathrm{N}$ by the nitrifiers which grow well in this condition [11, 18, 19]. Moreover, the DO concentrations less than $1.0 \mathrm{mg} / \mathrm{L}$ found in the $\mathrm{A}_{1}$ and $\mathrm{A}_{2}$ sections resulted in anoxic conditions which enabled for the occurrence of denitrification processes [20].

\subsection{Removal Efficiencies of the Modified AG-AOAR}

After the modified AG-AOAR reached the steady-state conditions, the evaluation of substrate removal under different loading rates along various HRTs was undertaken. As presented in Table 2, TSS, COD, TN, and $\mathrm{NH}_{4}-\mathrm{N}$ were selected as the critical parameters for evaluating the modified AG-AOAR performance.

Because of the highly polluted septic tank effluent feeding, the initial influent TSS as concentrations were 1,994.2 \pm 796, 1,234.6 \pm 78 and $392.7 \pm 300 \mathrm{mg} / \mathrm{L}$ at HRTs of 24,48 and $72 \mathrm{~h}$, respectively. The TSS removal efficiencies under the various HRTs were not significantly difference $(p<0.05)$; hence, the average TSS efficiency of the modified AG-AOAR was obtained to be $95.6 \pm 2 \%$, resulting an average effluent TSS concentration of $12.2 \mathrm{mg} / \mathrm{L}$ which could meet the effluent standard of the International Organization for Standardization (ISO) 30500: Non-Sewered Sanitation system [21] and domestic wastewater discharge standards of Thailand [22] (Table 2). Due to of the high removal efficiencies of the modified AG-AOAR, the TSS removal mechanisms were hypothesized to be mainly due to filtration throughout the zeolite beads and sedimentation.

Furthermore, the highest COD removal efficiency of $83.8 \pm 4 \%$ was found in the AG-AOAR at the OLR of $0.35 \mathrm{gCOD} /(\mathrm{L}-\mathrm{d})(\mathrm{P}$ $<0.05$ ) and HRT of $72 \mathrm{~h}$; accordingly, the effluent COD concentration was $109.9 \pm 28.9 \mathrm{mg} / \mathrm{L}$, meeting the effluent COD standards of the type B of the ISO:30500 $(<150 \mathrm{mg} / \mathrm{L})$ and wastewater discharge standards of Thailand $(<120 \mathrm{mg} / \mathrm{L})$ as revealed in Table 2 . Nevertheless, due to high levels of the OLR, the COD removal efficiencies of the AG-AOAR operating under the HRTs of 48 and $24 \mathrm{~h}$ were found to be $79 \pm 2.5 \%$ and $78.2 \pm 11 \%$, respectively.

The TN removal efficiencies were found to increase from 50 $\pm 17 \%$ to $66.1 \pm 11 \%\left(\mathrm{R}^{2}=0.97\right)$ with increasing HRT from 24 to $72 \mathrm{~h}$, respectively (Table 3). Accordingly, the effluent TN concentrations were decreased from $91.8 \pm 26.3$ to $66.1 \pm 10.9 \mathrm{mg} / \mathrm{L}$ when the NLRs were decreased from 0.18 to $0.06 \mathrm{gN} /(\mathrm{L}-\mathrm{d})$. Similarly, the $\mathrm{NH}_{4}-\mathrm{N}$ removal efficiencies were found to be $79.3 \pm 59 \%$, $83.2 \pm 3 \%$ and $91.4 \pm 3 \%(\mathrm{P}<0.05)\left(\mathrm{R}^{2}=0.96\right)$ at the $\mathrm{NH}_{4} \mathrm{LR}$ of $0.16,0.08$ and $0.05 \mathrm{gNH}_{4}-\mathrm{N} / \mathrm{L}$, respectively (Table 2). Accordingly, the average effluent $\mathrm{NO}_{\mathrm{X}}-\mathrm{N}$ concentrations were found to be about

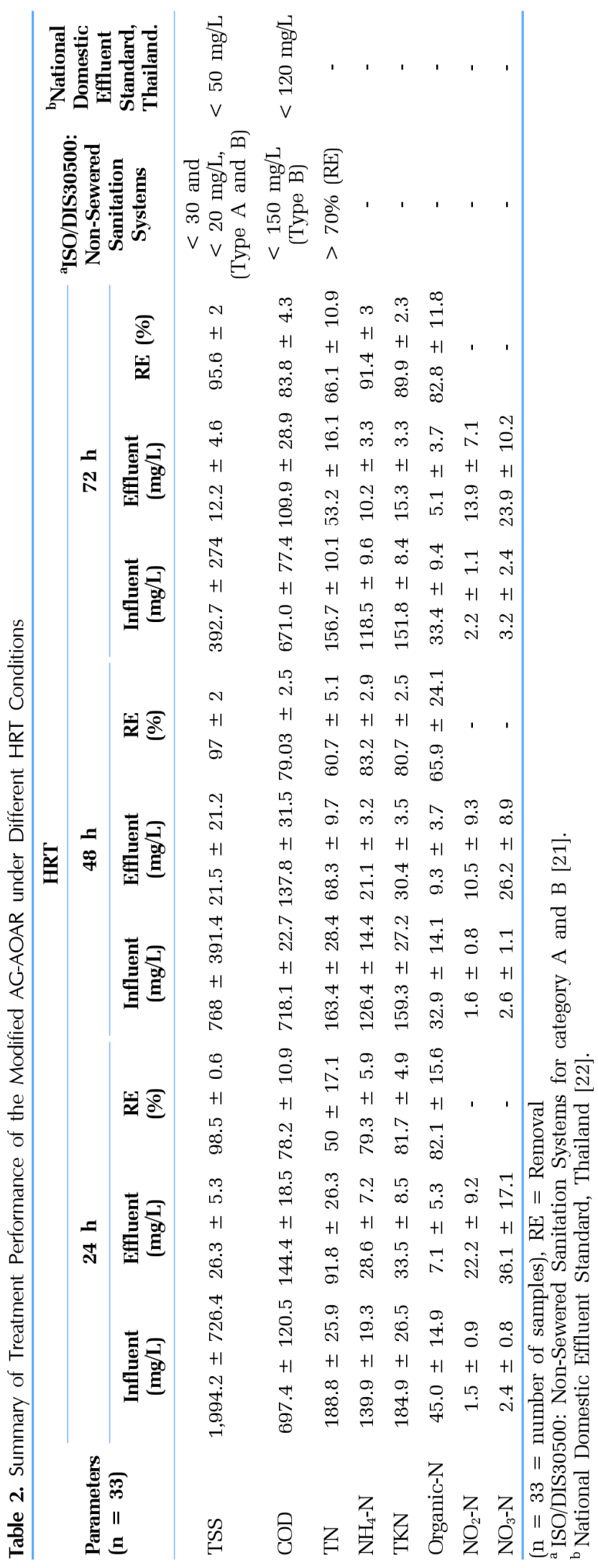



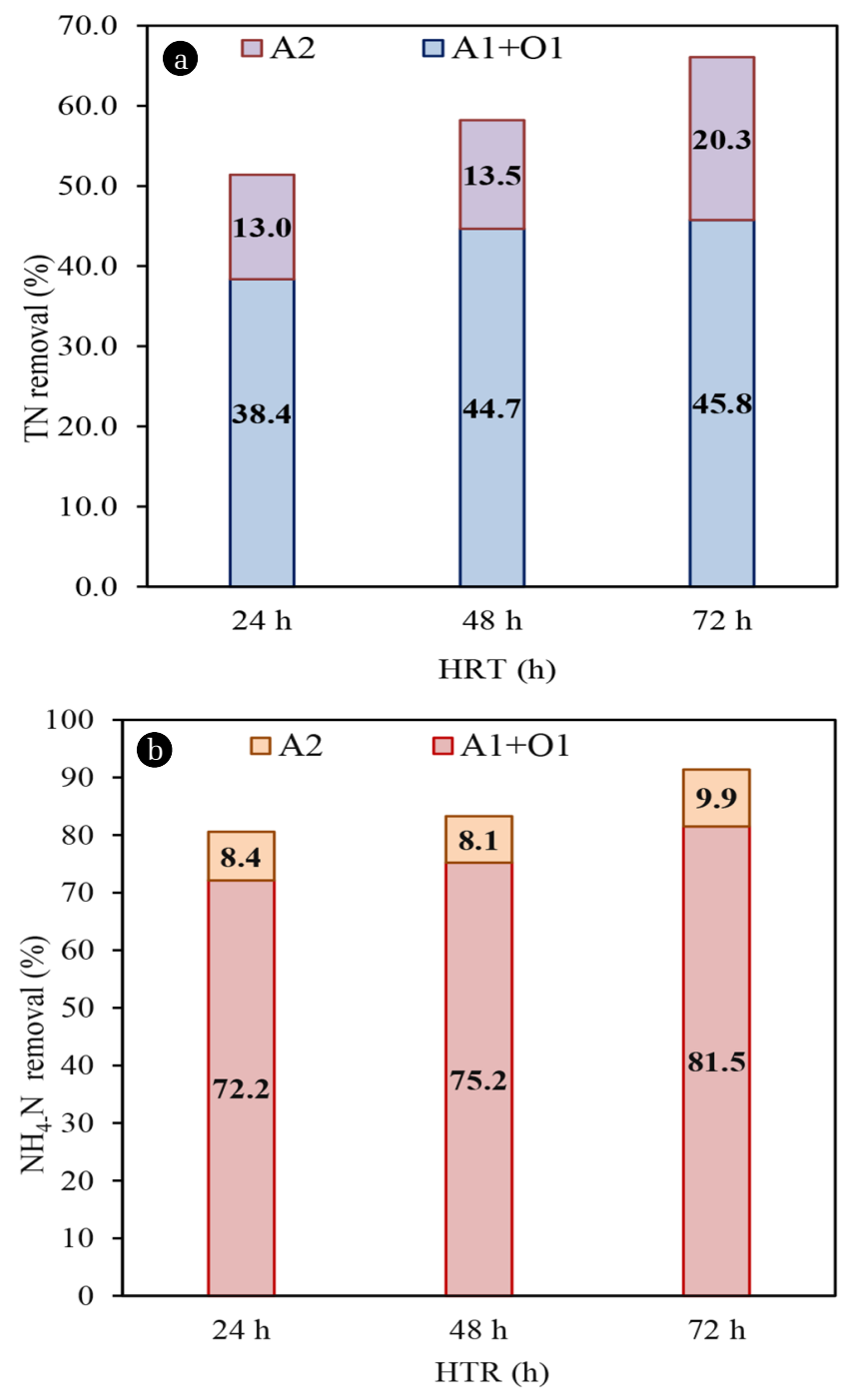

Fig. 2. (a) $\mathrm{TN}$ removal and (b) $\mathrm{NH}_{4}-\mathrm{N}$ removal under different HRTs.

$22 \mathrm{mg} / \mathrm{L}$, indicating that the nitrification reactions performed well in the modified AG-AOAR. Moreover, as shown in Fig. 3, the TN and $\mathrm{NH}_{4}-\mathrm{N}$ concentrations in the influent wastewater were mainly removed in the $A_{1}$ and $O_{1}$ sections. This could be due to recirculation of the wastewater from the $A_{2}$ to $A_{1}$ sections which could supply enough $\mathrm{NO}_{\mathrm{X}} \mathrm{-N}$ concentrations and COD concentration for enhancing denitrification processes in the $\mathrm{A}_{1}$ section [20]. Simultaneously, the $21.4 \%$ and $10 \%$ of $\mathrm{TN}$ and $\mathrm{NH}_{4}-\mathrm{N}$ removal in the $\mathrm{A}_{2}$ section, was hypothesized to be due to $\mathrm{NH}_{4}-\mathrm{N}$ absorption of the zeolite beads placed in this section (Fig. 2) [6]. Moreover, due to the attached-growth bacteria such as denitrifiers forming on the zeolite beads, some TN concentrations could be removed via the denitrification processes in the $\mathrm{A}_{2}$ section as well [23].

\subsection{Determination of Kinetic Coefficients}

The Stover-Kincannon model were employed to determine the kinetic coefficients of COD, $\mathrm{NH}_{4}-\mathrm{N}$ and TN removal in the modified AG-AOAR.

\subsubsection{Kinetic of COD removal}

As shown in Fig. 3, the values of $K_{B}$ and $\mu_{\max }$ for COD removal were obtained as 57.65, $41.17 \mathrm{~g} /(\mathrm{L}-\mathrm{d})$, respectively. The correlation coefficient of $\mathrm{R}^{2}$ was equal to 0.97 which illustrates a good agreement between the prediction and the experiment data of the modified AG-AOAR. Rate expression for these 2 kinetic coefficients can be used to determine the effluent COD concentration and, required volume of the modified AG-AOAR according to the Eq. (6) and (7), respectively.

Table 3 comparison of the kinetic coefficients of various types of the attached-growth reactor. The $\mu_{\max }$ and $K_{B}$ for COD removal of this study were relatively higher than other studies such as up-flow anoxic-aerobic sludge reactor [13], up-flow aerobic-anoxic sludge bed reactor [24], integrated anaerobic-aerobic reactor [25], up-flow aerobic anoxic sludge fixed film [7], moving bed biofilm reactors [5, 26-28], biofilm processes [10, 29], modified septic tank system [29], anaerobic-anoxic-aerobic moving bed bioreactors [20], and integrated rotating biological contactor-activated sludge system [31]. However, the values of $\mu_{\max }$, and $K_{B}$ in this study were lower than those of the down-flow hanging sponge bioreactor by Nga [32], probably which used lower strength wastewater in their studies.

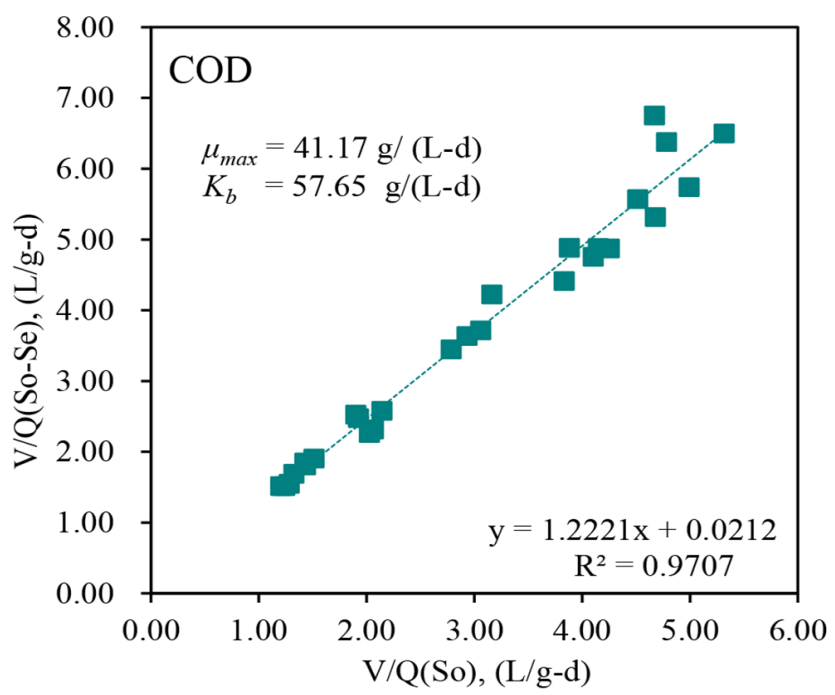

Fig. 3. Stover-Kincannon model plot for COD removal in the modified AG-AOAR.

\subsubsection{Kinetic of $\mathrm{NH}_{4}-\mathrm{N}$ removal}

Fig. 4 indicates the linear relationship between $V Q /\left(S_{0}-S_{e}\right)$, and $\mathrm{V} /\left(\mathrm{QS}_{\mathrm{o}}\right)\left(\mathrm{R}^{2}=99\right)$. From this result, the $\mu_{\max }$ and $\mathrm{K}_{\mathrm{B}}$ values for $\mathrm{NH}_{4}-\mathrm{N}$ removal were calculated to be 0.50 and $0.51 \mathrm{~g} /(\mathrm{L}-\mathrm{d})$, respectively. Rate expression for these 2 kinetic coefficients can be used to determine the effluent $\mathrm{NH}_{4}-\mathrm{N}$ concentration and the required volume of the modified AG-AOAR according to the Eq. (6) and (7), respectively. The $\mu_{\max }$ and $K_{B}$ values of the modified AG-AOAR were comparable those of the previous study as illustrated in Table 3. Probably due to the operated HRTs were not sufficient for nitrification processes, the obtained kinetic coefficients for $\mathrm{NH}_{4}-\mathrm{N}$ removal of this study were relatively lower than those of other 


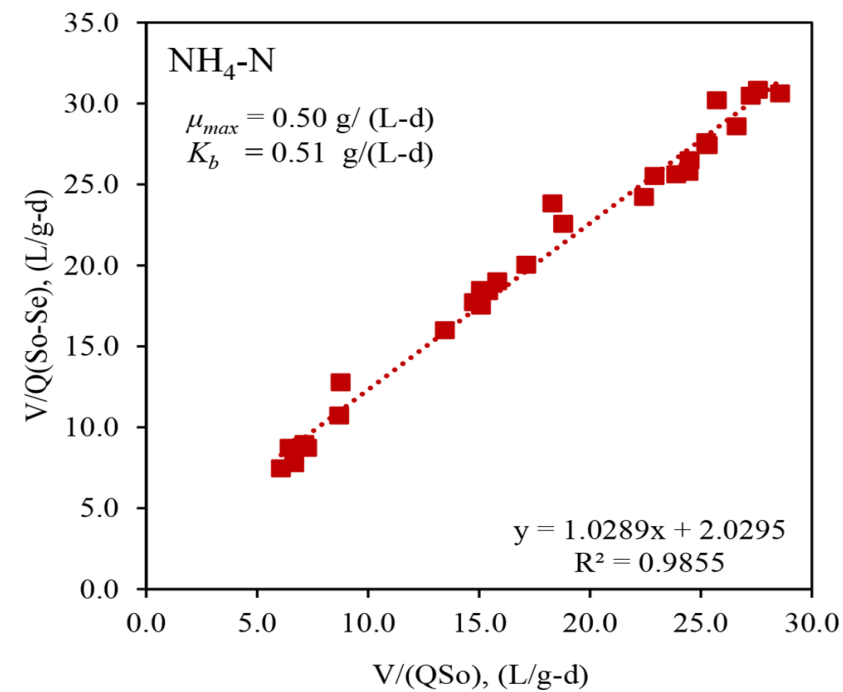

Fig. 4. Stover-Kincannon model plot for $\mathrm{NH}_{4}-\mathrm{N}$ removal in the modified AG-AOAR.

previous studies. Hence, it should be recommended that prolonging HRTs in the modified AG-AOAR is required for improving the $\mathrm{NH}_{4}-\mathrm{N}$ removal performance.

\subsubsection{Kinetic of TN removal}

The regression of the kinetic model for TN removal is revealed in Fig. $5\left(R^{2}=0.85\right)$. Accordingly, the $\mu_{\max }$ and $K_{B}$ values were obtained as 0.15 and $0.12 \mathrm{~g} /(\mathrm{L}-\mathrm{d})$, respectively. The results of $\mu_{\max }$

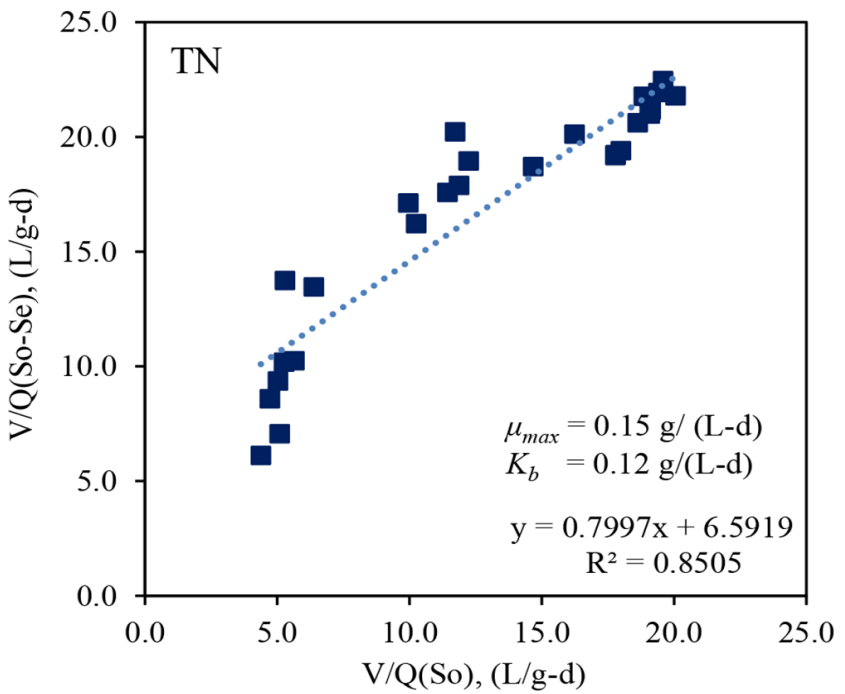

Fig. 5. Stover-Kincannon model plot for $\mathrm{TN}$ removal in the modified AG-AOAR.

and $K_{B}$ for TN removal in this study were higher than those of the previous study of [10]. Additionally, the Stover-Kincannon model were also previously applied for evaluating kinetic coefficients for TN removal in the up-flow anoxic-aerobic sludge reactor, the bio-diatomite biofilm reactor, the up-flow aerobic-anoxic sludge bed reactor, the up-flow anaerobic sludge bed-anammox reactor, the anaerobic-aerobic reactor and combined anaerobic aerobic systems [13, 17, 24, 33, 34].

Table 3. Kinetics of Stover-Kincannon Model Comparison with Other Related Studies

\begin{tabular}{|c|c|c|c|c|c|c|}
\hline Wastewater & Reactors & Substrates & $\begin{array}{c}\mu_{\max } \\
g /(L-d)\end{array}$ & $\begin{array}{c}\mathbf{K}_{\mathrm{B}} \\
\mathrm{g} /(\mathbf{L}-\mathbf{d})\end{array}$ & $\mathbf{R}^{2}$ & References \\
\hline \multirow{3}{*}{ Septic tank effluent } & \multirow{3}{*}{$\begin{array}{l}\text { Attached-growth anoxic-oxic-anoxic reactor } \\
\text { (Modified AG-AOAR) }\end{array}$} & COD & 41.2 & 57.7 & 0.97 & \multirow{3}{*}{ This study } \\
\hline & & $\mathrm{TN}$ & 0.15 & 0.12 & 0.85 & \\
\hline & & $\mathrm{NH}_{4}-\mathrm{N}$ & 0.50 & 0.51 & 0.99 & \\
\hline \multirow{2}{*}{ Synthetic wastewater } & \multirow{2}{*}{ Up-flow anoxic-aerobic sludge reactor } & COD & 24.75 & 25.97 & 0.99 & \multirow{2}{*}[13]{} \\
\hline & & $\mathrm{TN}$ & 0.334 & 0.314 & 0.95 & \\
\hline Palm oil mill effluent & Integrated anaerobic-aerobic reactor & COD & 23.1 & 14.7 & 0.67 & [25] \\
\hline Synthetic wastewater & Up-flow aerobic anoxic sludge fixed film reactor & COD & 38.5 & 37.9 & 0.99 & [7] \\
\hline Textile wastewater & Moving bed biofilm reactor & COD & 3.74 & 3.91 & 0.97 & [26] \\
\hline Domestic wastewater & Modified septic tank reactor & COD & 0.73 & 0.93 & 0.98 & [29] \\
\hline \multirow{2}{*}{ Septic tank effluent } & \multirow{2}{*}{ Biofilm reactor } & COD & 0.41 & 0.58 & 0.95 & \multirow{2}{*}{ [10] } \\
\hline & & $\mathrm{TN}$ & 0.03 & 0.04 & 0.85 & \\
\hline Septic tank effluent & Biofilm reactor & COD & 0.17 & 0.19 & 0.93 & [28] \\
\hline \multirow{2}{*}{ Municipal Wastewater } & \multirow{2}{*}{ Moving bed biofilm reactor } & COD & 10.1 & 11.2 & 0.95 & \multirow{2}{*}[5]{} \\
\hline & & $\mathrm{TN}$ & 5.34 & 4.25 & 0.96 & \\
\hline Synthetic wastewater & $\begin{array}{c}\text { Aerobic } \\
\text { (anaerobic-anoxic-aerobic moving bed bioreactor) }\end{array}$ & COD & 10.5 & 13.4 & 0.94 & \multirow{2}{*}{ [30] } \\
\hline Synthetic wastewater & $\begin{array}{c}\text { Anoxic } \\
\text { (anaerobic-anoxic-aerobic moving bed bioreactor) }\end{array}$ & COD & 15.1 & 27.2 & 0.98 & \\
\hline
\end{tabular}


Table 3. Continued

\begin{tabular}{|c|c|c|c|c|c|c|}
\hline Wastewater & Reactors & Substrates & $\begin{array}{l}\mu_{\max } \\
g /(L-d)\end{array}$ & $\begin{array}{c}K_{B} \\
g /(L-d)\end{array}$ & $\mathbf{R}^{2}$ & References \\
\hline Hospital wastewater & Moving bed biofilm reactor & COD & 10.0 & 9.9 & 0.99 & {$[27]$} \\
\hline \multirow{3}{*}{ Synthetic phenol wastewater } & $\begin{array}{c}\text { Anoxic (anaerobic-anoxic-aerobic batch fed moving } \\
\text { bed reactor) }\end{array}$ & COD & 5.00 & 5.95 & 0.97 & \multirow{3}{*}[20]{} \\
\hline & \multirow{2}{*}{$\begin{array}{l}\text { Aerobic (anaerobic-anoxic-aerobic batch fed moving } \\
\text { bed reactor) }\end{array}$} & COD & 1.00 & 2.13 & 0.99 & \\
\hline & & $\mathrm{NH}_{4}-\mathrm{N}$ & 3.33 & 4.33 & 0.96 & \\
\hline Polluted raw water & Bio-diatomite biofilm reactor & $\mathrm{TN}$ & 0.33 & 0.41 & 0.94 & {$[17]$} \\
\hline Domestic wastewater & Anaerobic-aerobic reactor & $\mathrm{TN}$ & 1.93 & 6.92 & 0.97 & {$[34]$} \\
\hline \multirow{2}{*}{ Industrial wastewater } & \multirow{2}{*}{ Up-flow aerobic-anoxic sludge bed reactor } & COD & 8.47 & 9.82 & 0.92 & \multirow{2}{*}[24]{} \\
\hline & & $\mathrm{TN}$ & 8.47 & 9.82 & 0.92 & \\
\hline \multirow{3}{*}{ Domestic wastewater } & \multirow{3}{*}{ A down-flow hanging sponge bioreactor } & COD & 56.81 & 75.03 & 0.99 & \multirow{3}{*}[32]{} \\
\hline & & $\mathrm{TN}$ & 2.81 & 8.37 & 0.99 & \\
\hline & & $\mathrm{NH}_{4}-\mathrm{N}$ & 2.96 & 4.71 & 0.99 & \\
\hline Synthetic wastewater & Activated sludge reactor & $\mathrm{NH}_{4}-\mathrm{N}$ & 0.89 & 1.01 & 0.94 & \multirow{2}{*}[33]{} \\
\hline Synthetic wastewater & Up-flow anaerobic sludge bed-anammox reactor & $\mathrm{TN}$ & 3.33 & 4.03 & 0.98 & \\
\hline \multirow{2}{*}{ Synthetic wastewater } & \multirow{2}{*}{$\begin{array}{l}\text { Integrated rotating biological contactor-activated } \\
\text { sludge reactor }\end{array}$} & COD & 15.2 & 14.9 & 0.81 & \multirow{2}{*}[31]{} \\
\hline & & $\mathrm{TN}$ & 10.98 & 7.11 & 0.96 & \\
\hline Domestic wastewater & Combined anaerobic-aerobic reactor & $\mathrm{TN}$ & 0.16 & 0.31 & 0.97 & {$[34]$} \\
\hline
\end{tabular}

In conclusion, the Stover-Kincannon model with the high $\mathrm{R}^{2}$ values of this study can be applicable to describe kinetic values for $\mathrm{COD}, \mathrm{NH}_{4}-\mathrm{N}$ TN removal in the modified AG-AOAR and for the determine the required reactor volume.

\section{Conclusions}

Based on the experimental results obtained for this study, the following conclusions can be drawn:

- The modified AG-AOAR could be effectively used as an effective on-site post-treatment system for removing COD, $\mathrm{NH}_{4}-\mathrm{N}$ and $\mathrm{TN}$ concentrations in septic tank effluent.

- The maximum COD, $\mathrm{NH}_{4}-\mathrm{N}$ and TN removal efficiencies were obtained as 83.8, 91.4 and $66.1 \%$ at the OLR, NLR and $\mathrm{NH}_{4} \mathrm{NLR}$ and HRT of 0.25 gCOD/(L-d), $0.05 \mathrm{gN} /(\mathrm{L}-\mathrm{d}), 0.05 \mathrm{gNH}_{4} \mathrm{-N} /(\mathrm{L}-\mathrm{d})$ and $72 \mathrm{~h}$, respectively.

- The Stover-Kincannon model showed the best fit to determine the kinetic values for $\mathrm{COD}$ and $\mathrm{NH}_{4}-\mathrm{N}$ removal in the modified AG-AOAR. The obtained kinetic values could be used for the design of the full-scale reactor.

\section{Acknowledgments}

The research was funded by the Royal Thai Government and the Bill \& Melinda Gates Foundation, USA, through the Asian Institute of Technology, Thailand under "Sustainable Decentralized Wastewater Management in Developing Countries: Design, Operation, and Monitoring Project”.

\section{Author Contributions}

T.K. (Professor) supervised the research and edited the manuscript. S.K. (Research associate) conducted the majority of the experiments and wrote the original draft. C.W. (Research associate) supported and revised writing the initial version of the manuscript. C.P. (Professor) provided guidance on the overall research activities.

\section{References}

1. Connelly S, Pussayanavin T, J Randle-Boggis R, et al. Solar septic tank: next generation sequencing reveals effluent microbial community composition as a useful index of system performance. Water 2019;11:2660.

2. Richards A, Withers PJA, Paterson E, McRoberts CW, Stutter M. Potential tracers for tracking septic tank effluent discharges in watercourses. Environ. Pollut. 2017;228:245-255.

3. UNSDG. United nations sustainable development goals: population information network [Internet]. c2020 [cited 1 October 2020]. Available from: https://www.un.org/sustainabledevelopment/water-and-sanitation/.

4. Abbassi BE, Abuharb R, Ammary B, Almanaseer N, Kinsley C. Modified septic tank: innovative onsite wastewater treatment system. Water 2018;10:578.

5. Barwal A. Influence of mathematical-kinetic models for the removal of organics and nutrients from municipal wastewater in moving bed biofilm reactor. Int. J. Sci. Res. Multidiscip. Stud. 2019;5:66-76.

6. Yang Y, Chen Z, Wang X, Zheng L, Gu X. Partial nitrification 
performance and mechanism of zeolite biological aerated filter for ammonium wastewater treatment. Bioresour. Technol. 2017;241:473-481.

7. Mansouri A, Zinatizadeh A, Akhbari A. Kinetic evaluation of simultaneous CNP removal in an up-flow aerobic/anoxic sludge fixed film (UAASFF) bioreactor. Iran. J. Energy Environ. 2014;5:323-336

8. Stover EL, Kincannon DF. Rotating biological contactor scale-up and design. Water Eng. Manage. 1982;129

9. Feng LJ, Mu J, Sun J, et al. Kinetic characteristics and bacterial structures in biofilm reactors with pre-cultured biofilm for source water pretreatment. Int. Biodeterior. Biodegradation 2017;121:26-34.

10. Chaiwong C, Koottatep T, Surinkul N, Polprasert C. Performance and kinetics of algal-bacterial photobioreactor (AB-PBR) treating septic tank effluent. Water Sci. Technol. 2018;78:2355-2363.

11. Metcalf E. Wastewater engineering treatment and resource recovery. 5th ed. New York: McGraw-Hill. Education; 2014.

12. Bernat K, Kulikowska D, Zielińska M, Cydzik-Kwiatkowska A, Wojnowska-Baryła I. Nitrogen removal from wastewater with a low COD/N ratio at a low oxygen concentration. Bioresour. Technol. 2011;102:4913-4916.

13. Abyar H, Younesi H, Bahramifar N, Zinatizadeh AA, Amini M. Kinetic evaluation and process analysis of COD and nitrogen removal in UAASB bioreactor. J. Taiwan. Inst. Chem. Eng. 2017;78:272-281.

14. Ahn YT, Kang ST, Chae SR, Lim JL, Lee SH, Shin HS. Effect of internal recycle rate on the high-strength nitrogen wastewater treatment in the combined UBF/MBR system. Water Sci. Technol. 2005;51:241-247.

15. Yan X, Han Y, Li Q, Sun J, Su X. Impact of internal recycle ratio on nitrous oxide generation from anaerobic/anoxic/oxic biological nitrogen removal process. Biochem. Eng. J. 2016;106:11-18.

16. APHA. Standard methods for the examination of water and wastewater. 23nd ed. United Book Press Inc. The United States of America; 2017.

17. Yang GF, Feng LJ, Wang SF, et al. Potential risk and control strategy of biofilm pretreatment process treating raw water. Bioresour. Technol. 2015;198:456-463.

18. Voa HNP, Buib XT, Nguyenb HH, et al. Effects of dissolved oxygen concentration on the performance of sponge membrane bioreactor treating hospital wastewater. Desalin. Water. Treat. 2019;151:128-137.

19. Liu G, Wang J. Long-term low DO enriches and shifts nitrifier community in activated sludge. Environ. Sci. Technol. 2013;47:5109-5117.

20. Sahariah BP, Chakraborty S. Performance of anaerobic-anoxic-aerobic batch fed moving-bed reactor at varying phenol feed concentrations and hydraulic retention time. Clean. Technol. Environ. Policy. 2013;15:225-233.

21. The ISO (the international Organization for Standardization). ISO/DIS30500: Non-sewered sanitation systems general safety and performance requirements for design and testing. Switzerland, Team ANSI ISO. 2018.

22. PCD (Pollution Control Department, Thailand). Standard quality of discharge for wastewater in Thailand [Internet]. PCD Thailand; c2017 [cited 15 September 2017]. Available from: http://www.pcd.go.th/info_serv/reg_std_water04. html\#s3.

23. Kamngam S, Koottatep T, Surinkul N, Chaiwong C, Polprasert C. Performance evaluation of anoxic-oxic-anoxic processes in illuminated biofilm reactor (AOA-IBR) treating septic tank effluent. J. Water. Sanit. Hyg. Dev. 2020;10:874-884.

24. Asadi A, Zinatizadeh AA, Sumathi S. Industrial estate wastewater treatment using single up-flow aerobic/anoxic sludge bed (UAASB) bioreactor: A kinetic evaluation study. Environ. Prog. Sustain. Energy. 2014;33:1220-1228.

25. Chan YJ, Chong MF, Law CL. Performance and kinetic evaluation of an integrated anaerobic-aerobic bioreactor in the treatment of palm oil mill effluent. Environ. Technol. 2017;38:1005-1021.

26. Ahmadi M, Amiri P, Amiri N. Combination of TiO 2-photocatalytic process and biological oxidation for the treatment of textile wastewater. Korean. J. Chem. Eng. 2015;32:1327-1332.

27. Shokoohi R, Asgari G, Leili M, Khiadani M, Foroughi M, Hemmat MS. Modelling of moving bed biofilm reactor (MBBR) efficiency on hospital wastewater (HW) treatment: a comprehensive analysis on BOD and COD removal. Int. J. Environ. Sci. Technol. (Tehran). 2017;14:841-852.

28. Surinkul N, Koottatep T, Chaiwong C, Singhopon T. Modified cesspool system with up-flow sludge tank and low-cost photobioreactor treating blackwater. Desalin. Water. Treat. 2017;91:329-335.

29. Sharma MK, Kazmi AA. Substrate removal kinetics of domestic wastewater treatment in a two-stage anaerobic system. Sep. Sci. Technol. 2015;50:2752-2758.

30. Sahariah BP, Chakraborty S. Kinetic analysis of phenol, thiocyanate, and ammonia-nitrogen removals in an anaerobic-anoxic-aerobic moving bed bioreactor system. J. Hazard. Mater. 2011;190:260-267.

31. Akhbari A, Zinatizadeh AAL, Mohammadi P, Mansouri Y, Irandoust $\mathrm{M}$, Isa $\mathrm{MH}$. Kinetic modeling of carbon and nutrients removal in an integrated rotating biological contactor-activated sludge system. Int. J. Environ. Sci. Technol. (Tehran). 2012;9:371-378.

32. Nga DT, Hiep NT, Hung NTQ, Nga DT, Hiep NT, Hung NTQ. Kinetic modeling of organic and nitrogen removal from domestic wastewater in a down-flow hanging sponge bioreactor. Environ. Eng. Res. 2020;25:243-250.

33. Niu Q, Zhang Y, Ma H, He S, Li YY. Reactor kinetics evaluation and performance investigation of a long-term operated UASB-anammox mixed culture process. Int. Biodeterior. Biodegradation. 2016;108:24-33.

34. Vandith V, Setiyawan AS, Soewondo P, Bophann P. Kinetics of nutrient removal in an on-site domestic wastewater treatment facility. In: MATEC Web of Conferences. EDP Sciences, 2018; p. 04004. 